\title{
HUBUNGAN DUKUNGAN SUAMI DENGAN PEMILIHAN KONTRASEPSI JANGKA PANJANG DI WILAYAH KERJA PUSKESMAS TAMANSARI KOTA TASIKMALAYA TAHUN 2013
}

Oleh :

Fenty Agustini, SST.,M.Kes

\section{A. Abstrak}

Pemilihan jenis kontrasepsi pada setiap wanita bergantung pada beberapa faktor diantaranya umur, jumlah keluarga yang diinginkan, paritas, pengalaman metode yang lalu, status kesehatan, efektifitas, pertimbangan efek samping dan biaya. Laporan Puskesmas Tamansari tahun 2012 cakupan AKDR sebanyak 5,70\%, Implan sebanyak 4,32\%, cakupan MOW sebanyak 0,47\%. Tujuan penelitian ini adalah untuk mengetahui hubungan dukungan suami dengan penggunaan kontrasepsi jangka panjang di Wilayah Kerja Puskesmas Tamansari Kota Tasikmalaya Tahun 2013.

Metode penelitian ini adalah analitik dan pendekatan cross sectional. Pengambilan sampel menggunakan teknik proportional random sampling, setelah dilakukan penelitian jumlah sampel sebanyak 372 orang. Data diperoleh menggunakan instrumen dan dianalisis dengan menggunakan univariat dan bivariat

Hasil penelitian ini diketahui terdapat hubungan antara dukungan suami dengan pemilihan kontrasepsi jangka panjang dengan (p value 0,002)

Kesimpulan dari penelitian ini adalah terdapat hubungan antara dukungan suami dengan pemilihan kontrasepsi jangka panjang. Pasangan usia subur agar meningkatkan pengetahuan program KB yang akhirnya dapat memilih kontrasepsi sesuai dengan tujuannya.

\section{Kata Kunci : Dukungan Suami, Pemilihan Kontrasepsi jangka panjang}




\section{B. Latar belakang}

Kuantitas jumlah penduduk Indonesia cukup besar, pada tahun 2010 penduduk Indonesia diperkirakan kurang lebih 228 juta jiwa, dengan pertumbuhan penduduk $1,64 \%$ dan total fertility rate (TFR) 2,6\%. tetapi dari segi kualitas melalui Indeks Pembangunan Manusia (IPM) Indonesia pada tahun 2011 berada diperingkat 124 dari 187 negara pada tahun 2011. Indeks Pembangunan Manusia (IPM) sendiri dipengaruhi oleh tiga hal pokok, antara lain pendidikan, kesehatan dan standar kehidupan yang diukur dari tingkat daya beli masyarakat atau pendapatannya dengan mengacu pada pendapatan per kapita. Ketiga hal ini bermuara pada kualitas hidup masyarakat suatu negara (BKKBN, 2012).

Pembangunan nasional ditujukan untuk meningkatkan kualitas penduduk yang merupakan potensi sumber daya manusia (SDM) sehingga dapat mendukung pelaksanaan pembangunan nasional yang berkelanjutan. Oleh karena itu, kebijakan program Kependudukan dan Keluarga Berencana (KKB) tidak sematamata sebagai upaya mempengaruhi pola dan arah demografi, tetapi juga untuk mencapai kesejahteraan masyarakat lahir dan batin bagi generasi sekarang dan generasi mendatang (BKKBN, 2012).

Keluarga Berencana (KB) merupakan salah satu pelayanan kesehatan preventif yang paling dasar dan utama bagi wanita, meskipun tidak selalu diakui demikian. Banyak wanita harus menentukan pilihan kontrasepsi yang sulit, tidak hanya karena terbatasnya jumlah metode yang tersedia tetapi juga karena metode-metode tertentu mungkin tidak dapat diterima sehubungan dengan kebijakan nasional Keluarga Berencana $(\mathrm{KB})$, kesehatan individual dan seksualitas wanita atau biaya untuk memperoleh kontrasepsi (Akmal, 2009).

Cakupan kontrasepsi jangka panjang yang digunakan di Indonesia antara lain Intra Uterine Devices (IUD) (6,2 \%), implan (4,3 \%), tubektomi $(3,7 \%)$, dan vasektomi $(0,4 \%)$. Berdasarkan laporan seluruh klinik Keluarga Berencana di Jawa Barat peserta Keluarga Berencana (KB) jangka panjang pada tahun 2008 sebanyak 1.149 .766 mencapai $10,61 \%$ (BKKBN Jabar, 2008).

Pemakaian waktu metode kontrasepsi pada setiap wanita bergantung pada beberapa faktor. Menurut Proverawati (2010) beberapa faktor yang berperan dalam pemilihan kontrasepsi diantaranya umur, jumlah keluarga yang diinginkan, paritas, pengalaman metode yang lalu, status kesehatan, efektifitas, pertimbangan efek samping dan biaya. Pemilihan kontrasepsi juga didasarkan pada tujuan dari penggunaan kontrasepsi tersebut yakni menunda menjarangkan, atau mengakhiri kehamilan.

Berdasarkan data yang diperoleh dari Kantor Keluarga Berencana dan Pemberdayaan Perempuan Kota Tasikmalaya, pada tahun 2011 jumlah Pasangan Usia Subur sebanyak 117992 orang dan peserta KB aktif sebanyak 87311 orang, dari jumlah tersebut yang menggunakan Alat Kontrasepsi Dalam Rahim (AKDR) sebanyak 8,69\%, implan sebanyak 2,61\%, Metode Operasi Wanita (MOW) sebanyak 1,34\% dan Metode Operasi Pria (MOP) sebanyak 6,12\%. Pada tahun 2012 jumlah Pasangan Usia Subur (PUS) sebanyak 120535 orang dan peserta KB aktif sebanyak 90286 orang, dari jumlah tersebut yang menggunakan Alat Kontrasepsi Dalam Rahim (AKDR) sebanyak 12,61\%, implan sebanyak 3,52\%, Metode Operasi Wanita (MOW) sebanyak $1,79 \%$ dan Metode Operasi Pria (MOP) sebanyak 0,15\%.

Kecamatan Tamansari merupakan daerah dengan jumlah pengguna metode kontrasepsi jangka panjang cukup rendah. Pada tahun 2011 jumlah pengguna Alat Kontrasepsi Dalam Rahim (AKDR) sebanyak 5,75\%, Implan sebanyak 4,80\%, Metode Operasi Wanita (MOW) 0,52\% dan Metode Operasi Pria (MOP) 0,08\% dari jumlah peserta aktif sebanyak 11775 orang. Hal ini lebih kecil dibandingkan dengan Kecamatan Tawang dengan jumlah 
peserta implan sebanyak 2,52\%, Alat Kontrasepsi Dalam Rahim (AKDR) sebanyak 25,38\%, Metode Operasi Wanita (MOW) sebanyak 3,78\% dan Metode Operasi Pria (MOP) sebanyak 0,33\%.

Sedangkan pada tahun 2012 mengalami penurunan yaitu pengguna Alat Kontrasepsi Dalam Rahim (AKDR) sebanyak 5,70\%, Implan sebanyak 4,32\%, cakupan Metode Operasi Wanita (MOW) sebanyak 0,47\% dan Metode Operasi Pria (MOP) sebanyak $0,07 \%$ dari jumlah peserta aktif sebanyak 13710 orang lebih kecil dibandingkan dengan Kecamatan Tawang dengan jumlah peserta implan sebanyak 2,62\%, Alat Kontrasepsi Dalam Rahim (AKDR) sebanyak 26,69\%, Metode Operasi Wanita (MOW) sebanyak 4,07\% dan Metode Operasi Pria (MOP) sebanyak $0,34 \%$.

Menurut data Badan Keluarga Berencana dan Pemberdayaan Perempuan (BKBPP), yang bersumber dari rekapitulasi laporan bulanan klinik Keluarga Berencana dan laporan pengendalian lapangan program Keluarga Berencana nasional tingkat kecamatan, hitungan kasar peserta Keluarga Berencana

\section{Metode}

Jenis penelitian yang digunakan adalah kuantitatif dengan metode analitik dan rancangan cross sectional yaitu suatu metode penelitian yang bertujuan untuk mengetahui faktor dukungan suami yang berhubungan dengan pemilihan kontrasepsi jangka panjang di Wilayah Kerja Puskesmas Tamansari Kota Tasikmalaya tahun 2013. yang drop out hingga Juni tahun 2013 sebanyak 6.757 atau 5,16\%. Dari jumlah 6.757 atau $5,16 \%$ peserta $\mathrm{KB}$ yang drop out di seluruh Kota Tasikmalaya tersebut, jika dipersentasi terbanyak adalah peserta dari Kecamatan Tamansari yakni 7,21\%. Kemudian jumlah peserta KB drop out, paling rendah di Kecamatan Mangkubumi sebesar 2,29\%. Metode kontrasepsi jangka panjang ini memiliki efektivitas sampai 99 persen dengan tingkat kegagalan hanya 0,05 dari 100 wanita yang memakainya.

Menurut informasi yang diperoleh dari Bidan Koordinator Puskesmas Tamansari mengenai penggunaan kontrasepsi oleh wanita usia subur masih memiliki kendala, diantaranya sebagian wanita usia subur memilih metode kontrasepsi tanpa memperhatikan indikasi dan kontraindikasi jenis kontrasepsi yang dipilihnya.

Penelitian ini bertujuan untuk mengetahui hubungan antara dukungan suami dengan penggunaan kontrasepsi jangka panjang di Wilayah Kerja Puskesmas Tamansari Kota Tasikmalaya Tahun 2013.

Populasi dalam penelitian ini adalah seluruh akseptor $\mathrm{KB}$ yang berlokasi di Wilayah Kerja Puskesmas Tamansari Kota Tasikmalaya periode bulan April tahun 2013 yaitu sebanyak 11583 orang.

Selanjutnya dilakukan pengambilan sampel dari tiap kelurahan dengan teknik proportional random sampling. 
Tabel 3.1 Sebaran Sampel dari tiap Kelurahan

\begin{tabular}{|l|c|c|c|c|}
\hline Kelurahan & Peserta aktif & Total Populasi & Total sampel & Sampel \\
\hline Tamansari & 1344 & 11583 & 372 & 43 \\
\hline Mugarsari & 1062 & 11583 & 372 & 34 \\
\hline Tamanjaya & 1575 & 11583 & 372 & 51 \\
\hline Sumelap & 1003 & 11583 & 372 & 32 \\
\hline Setiawargi & 1491 & 11583 & 372 & 48 \\
\hline Mulyasari & 1864 & 11583 & 372 & 60 \\
\hline Sukahurip & 2050 & 11583 & 372 & 66 \\
\hline Setiamulya & 1194 & 11583 & 372 & 38 \\
\hline Jumlah & $\mathbf{1 1 5 8 3}$ & & & $\mathbf{3 7 2}$ \\
\hline
\end{tabular}

Pemilihan sampel berdasarkan atas kriteria dengan mengacu kepada indikasi dan kontraindikasi dari akseptor kontrasepsi jangka panjang :

a. Kriteria Inklusi

1) Sesuai dengan Indikasi implan

2) Sesuai dengan Indikasi Alat Kontrasepsi Dalam Rahim

3) Sesuai dengan indikasi Metode Operasi Wanita

4) Sesuai dengan indikasi Metode Operasi Pria

b. Kriteria Ekslusi

1) Kondisi akseptor KB tidak sehat

2) Tidak berada di tempat saat dilakukan penelitian

3) Tidak bersedia menjadi responden

Teknik pengambilan sampel dilakukan dengan menggunakan random sederhana berupa pengambilan kertas undian. Apabila terdapat sampel yang tidak bisa dijadikan responden, maka dilakukan pengocokan kembali.

Instrumen dalam penelitian ini berupa format cek list yang terdiri dari 10 pernyataan untuk mengetahui dukungan suami dan penggunaan kontrasepsi jangka panjang.

Adapun langkah-langkah pengolahan data dalam penelitian ini adalah sebagai berikut :

Proses Editing

Proses Coding

Proses Tabulating

Proses Entrying

\section{Analisa Data}

a. Analisis Data

1) Analisis Univariat

Analisis univariat adalah analisis yang menghasilkan data distribusi frekuensi dan dipersentasekan serta dianalisis dalam bentuk narasi, selanjutnya dianalisis dan disesuaikan dengan teori yang ada.

2) Analisis Bivariat

Analisis bivariat digunakan untuk melihat hubungan antara variabel sesuai dengan tujuan penelitian maka analisa bivariat dilakukan untuk melihat hubungan antara variabel dependen dengan independen dengan menggunakan $\mathrm{Uji}$ ChiSquare dengan rumus :

$$
\begin{aligned}
& \mathrm{X}^{2}=\sum \frac{(O-E)^{2}}{E} \\
& \mathrm{E}=\frac{\text { Total Baris } \mathrm{x} \text { Total Kolom }}{\text { Seluruh Data }}
\end{aligned}
$$

Keterangan:

$\mathrm{X}^{2}=$ Chi-square

$\mathrm{O}=$ Nilai Observasi

$\mathrm{E}=$ Nilai expected (harapan)

Kriteria pengujian dengan menggunakan distribusi $p$ value $<0.05$. Apabila hasil uji statistik $\mathrm{p}<0.05$ artinya ada hubungan yang bermakna Ho ditolak dan $\mathrm{H}_{1}$ diterima artinya terdapat hubungan, namun sebaliknya apabila $p$ value $>0.05$ maka Ho diterima dan $\mathrm{H}_{1}$ ditolak artinya tidak terdapat hubungan.

Selanjutnya dilakukan analisis bivariat dilakukan untuk melihat besar 
risiko dengan menghitung nilai $O R$ (Odd rasio) dengan menggunakan rumus :

$$
\begin{aligned}
\varphi & =\frac{a d}{b c} \\
\varphi & =\text { besar risiko } \\
\mathrm{a} & =\text { baris ke } 1 \text { kolom ke } 1 \\
\mathrm{~b} & =\text { baris ke } 1 \text { kolom ke } 2 \\
\mathrm{c} & =\text { baris ke } 2 \text { kolom ke } 1 \\
\mathrm{~d} & =\text { baris ke } 2 \text { kolom ke } 2
\end{aligned}
$$

\section{Hasil penelitian}

Analisis Univariat

1. Pemilihan kontrasepsi jangka panjang

Tabel Distribusi frekuensi pemilihan kontrasepsi jangka panjang di Wilayah Kerja Puskesmas Tamansari Kota Tasikmalaya tahun 2013

\begin{tabular}{|l|c|c|}
\hline \multicolumn{1}{|c|}{ Pemilihan kontrasepsi } & Jumlah & Persentase (\%) \\
\hline Ya & 112 & 30.1 \\
\hline Tidak & 260 & 69.9 \\
\hline Jumlah & 372 & 100.0 \\
\hline
\end{tabular}

Data pada tabel diatas menunjukkan kurang dari $2 / 3$ responden tidak memilih kontrasepsi jangka panjang

2. Dukungan Suami

Tabel Distribusi frekuensi dukungan suami terhadap responden di Wilayah Kerja Puskesmas Tamansari Kota Tasikmalaya tahun 2013

\begin{tabular}{|l|c|c|}
\hline \multicolumn{1}{|c|}{ Dukungan Suami } & Jumlah & Persentase (\%) \\
\hline Mendukung & 118 & 31.7 \\
\hline Tidak mendukung & 254 & 68.3 \\
\hline Jumlah & 372 & 100.0 \\
\hline
\end{tabular}

Data pada tabel diatas menunjukkan lebih dari $2 / 3$ responden tidak mendapat dukungan suami terkait dengan penggunaan kontrasepsi

\begin{tabular}{|c|c|c|c|c|c|c|c|c|}
\hline \multirow{3}{*}{$\begin{array}{c}\text { Dukungan } \\
\text { suami }\end{array}$} & \multicolumn{4}{|c|}{$\begin{array}{c}\text { Kontrasepsi jangka } \\
\text { panjang }\end{array}$} & \multirow{2}{*}{\multicolumn{2}{|c|}{ Total }} & \multirow{3}{*}{$P$ value } & \multirow{3}{*}{$O R$} \\
\hline & \multicolumn{2}{|c|}{ Ya } & \multicolumn{2}{|c|}{ Tidak } & & & & \\
\hline & $\mathbf{F}$ & $\%$ & $\mathbf{F}$ & $\%$ & Jml & $(\%)$ & & \\
\hline Mendukung & 49 & 41.5 & 69 & 58.5 & 118 & 100 & \multirow[b]{2}{*}{0,002} & \multirow[b]{2}{*}{10,70} \\
\hline $\begin{array}{l}\text { Tidak } \\
\text { mendukung }\end{array}$ & 63 & 24.8 & 191 & 75.2 & 254 & 100 & & \\
\hline Jumlah & 112 & 30,1 & 260 & 69,9 & 372 & 100 & & \\
\hline
\end{tabular}

\section{Analisis Bivariat}

Hubungan antara dukungan suami dengan pemilihan kontrasepsi jangka panjang.

Tabel hubungan antara dukungan suami dengan pemilihan kontrasepsi jangka panjang di Wilayah Kerja Puskesmas Tamansari Kota Tasikmalaya

Tahun 2013. 
Data pada tabel diatas menunjukkan sebanyak $41,5 \%$ ibu yang mendapat dukungan suami memilih kontrasepsi jangka panjang. Sebanyak $24,8 \%$ ibu yang tidak mendapat dukungan dari suami memilih kontasepsi jangka panjang. Berdasarkan hasil analisis didapat nilai $p$ value sebesar 0,002 artinya terdapat

\section{E. Pembahasan}

Data dari hasil penelitian diperoleh sebanyak $41,5 \%$ ibu yang mendapat dukungan suami memilih kontrasepsi jangka panjang. Sebanyak $24,8 \%$ ibu yang tidak mendapat dukungan dari suami memilih kontasepsi jangka panjang. Berdasarkan hasil analisis didapat nilai $p$ value sebesar 0,002 artinya terdapat hubungan antara pemanfaatan pelayanan kesehatan dengan pemilihan kontrasepsi jangka panjang. Ibu yang mendapat dukungan dari suami berpeluang sebesar 10,7 untuk memilih kontrasepsi jangka panjang dibandingkan dengan ibu yang tidak mendapat dukungan dari suami.

Berdasarkan data tersebut penulis berpendapat bahwa suami berperan dalam menentukan kesehatan reproduksi istri. Adanya dukungan suami yang positif dapat menjadi stimulus bagi istri untuk menggunakan kontrasepsi. Menurut Rizarina (2004) dukungan merupakan salah satu faktor penguat (reinforcing factor) yang dapat mempengaruhi seseorang dalam berperilaku. Sedangkan dukungan suami dalam KB merupakan bentuk nyata dari kepedulian dan tanggung jawab para pria.

Berdasarkan hasil penelitian diperoleh data bahwa sebanyak $44 \%$ ibu yang memanfaatkan pelayanan kesehatan memilih kontrasepsi jangka panjang. Sebanyak 26,6\% ibu yang tidak memanfaatkan pelayanan kesehatan memilih kontasepsi jangka panjang. Berdasarkan hasil analisis didapat nilai $p$ value sebesar 0,005 artinya terdapat hubungan antara pemanfaatan pelayanan kesehatan dengan pemilihan kontrasepsi jangka panjang. Ibu yang memanfaatkan hubungan antara pemanfaatan pelayanan kesehatan dengan pemilihan kontrasepsi jangka panjang. Ibu yang mendapat dukungan dari suami berpeluang sebesar 10,7 kali untuk memilih kontrasepsi jangka panjang dibandingkan dengan ibu yang tidak mendapat dukungan dari suami.

pelayanan kesehatan berpeluang sebesar 2,16 untuk memilih kontrasepsi jangka panjang dibandingkan dengan ibu yang tidak memanfaatkan pelayanan kesehatan.

Berdasarkan data diatas penulis berpendapat bahwa responden yang berkunjung ke fasilitas kesehatan untuk melakukan konsultasi masalah kesehatan reproduksi khususnya dalam masalah alat kontrasepsi memiliki kecenderungan dapat berperilaku sesuai dengan informasi yang diperoleh dari tempat pelayanan kesehatan tersebut.

\section{F. Simpulan dan saran}

Berdasarkan hasil penelitian dan pembahasan mengenai faktor dukungan suami yang berhubungan dengan pemilihan kontrasepsi jangka panjang di Wilayah Kerja Puskesmas Tamansari Kota Tasikmalaya Tahun 2013, maka penulis dapat menyimpulkan bahwa penggunaan kontrasepsi jangka panjang di Wilayah Kerja Puskesmas Tamansari Kota Tasikmalaya Tahun 2013 sebagian besar tidak memilih kontrasepsi jangka panjang $(69,9 \%)$ dan terdapat hubungan antara dukungan suami dengan pemilihan kontrasepsi jangka panjang di Wilayah Kerja Puskesmas Tamansari Kota Tasikmalaya Tahun 2013 dengan $p$ value 0,002.Ibu yang mendapat dukungan suami sebanyak $31,7 \%$ dan berpeluang sebesar $41,5 \%$ untuk memilih kontrasepsi jangka panjang. Sehingga ibu yang mendapat dukungan dari suami memiliki kontribusi sebesar $13 \%$ terhadap pemilihan kontrasepsi jangka panjang.

Perlu dilakukan upaya peningkatan cakupan kontrasepsi melalui optimalisasi safari KB yang dilakukan secara rutin dan 
berkesinambungan dengan mengintegrasikan program KB yang terdiri dari promosi $\mathrm{KB}$ serta memberikan pelayanan medik.

\section{G. Referensi}

Akmal (2009) Jenis-jenis Kontrasepsi

Program KB, tersedia dalam :

http://www.bkkbn.go.id/Webs/Kon sultasi.aspx; diakses tanggal 31

April 2013

Angio, 2011. Faktor-faktor yang berhubungan dengan pemilihan alat kontrasepsi hormonal di wilayah kerja Puskesmas Manyaran Semarang. Dari: http://poltekkes.smg.ac.iddiases bulan Juni 2013

BKKBN. 2009. Alat Kontrasepsi Dalam Rahim

.Dari http://www.bkkbn.go.id Tulisan diakses tanggal 17 Februari 2013

BKKBN Jabar, 2008. Kont Kontrasepsi. Dari http://www.bkkbn.go.id Tulisan diakses tanggal 17 Februari 2013

BKKBN, 2007. BBKBN, (2007). Pilihan KB Yang Rasional. http://pikas.bkkbn.go.id/

BKKBN. 2012. Tingkatkan Kualitas Manusia Melalui KB. http://www.bkkbn/go.id

Hanafiah. 2004. Metode Kontrasepsi Bagi Wanita. http://medica.online.com

Handayani. 2010. Buku Ajar Pelayanan Keluarga Berencana. Pustaka Rihama. Yogyakarta.

Hartanto, 2004. Keluarga Berencana. EGC. Jakarta

Indrawati, 2011. Analisis Faktor Kebijakan dan Pengetahuan Tentang Pelayanan KB yang Berhubungan dengan Pemilihan Alat Kontrasepsi IUD pada Ibu Pasangan Usia Subur Akseptor KB di kecamatan Pedurungan Kota Semarang. Dari http://www.undip.ac.iddiases bulan Juni 2011
Ismail. 2012. Kerangka Teori Penelitian. http://id.scribd.com/doc

Kontrasepsi pada wanita usia subur (Studi di Kelurahan Cipari Kota Tasikmalaya). Dari http://www.unsil.ac.id diases bulan Juni 2013

Krisnadi, S. R. 2007. Reproduksi dan Kontrasepsi. dari : http://www.ibuhamil.com/ diakses tahun 2013.

Kusmaryanto, 2009. Kontrasepsi. Dari http://www.google.com. Tulisan diakses tanggal Mei 2013

Manuaba, Ida Bagus Gede. 2006. Ilmu Kebidanan, Penyakit Kandungan dan KB. EGC. Jakarta

Notoatmodjo. 2005. Promosi Kesehatan: Ilmu dan Seni. Rhineka Cipta. Jakarta

Notoatmodjo. 2007. Kesehatan Masyarakat: Teori dan Aplikasi. Rhineka Cipta. Jakarta

Nuraidah, 2000. Faktor-faktor yang berhubungan dengan pemilihan alat kontrasepsi MKET dan non-MKET pada akseptor KB di kelurahan pasir putih dan Bungo Timur Kecamatan Muara Bungo Kabupaten Bungo Jambi Periode 1999/2000. Dari http:// http://ww.ui.ac.id diases bulan Juni 2013

Pantiawati. 2011. Bayi dengan BBLR (Berat Badan Lahir Rendah). Medical Book. Jakarta

Proverawati, 2010. Panduan Memilih Kontrasepsi. Nuha Medika. Jakarta 